\title{
CSI, voor open sociale innovatie
}

\section{Column}

\author{
Fietje Vaas*
}

Uitvoeren van een programma voor 'marketing, manpower utilization, work organization, techniques for labour and management cooperation and training'. Dat zou een goede omschrijving kunnen zijn van de missie van het in juni 2006 opgerichte Centrum voor Sociale Innovatie (CSI).

Het waren evenwel de doelen van het Technical Assistance Programme voor de overdracht van Amerikaanse managementkennis aan Nederlandse managers, onderdeel van een overeenkomst tussen de regeringen van de Verenigde Staten en Nederland getekend in 1948 in het kader van het marshallplan. Uit dit programma kwam direct de Stichting Contactgroep Opvoering Productiviteit (COP) voort. Dat werd later, in 1962 de SER commissie COP, die tot 1991 zou voortbestaan als Commissie Ontwikkeling Bedrijven (COB/SER).

De COP heeft, later als COB/SER - zelfs tot na haar opheffing in 1991 - zeer veel projecten uitgevoerd en publicaties uitgebracht die relevant zijn voor sociale innovatie. In 1985 organiseerde de COB een 'open bijeenkomst' voor haar Contactraad (waarin bedrijfsleven en professionals) over 'Flexibiliteit en sociale innovatie' en in 1988 over 'Kwaliteit van Werk en Organisatie'.

'Sociale Innovatie' is als term dus niet zo nieuw. Met TNO-collega's schreef ik in 1987 een boekje met de titel: Sociaal inventief automatiseren. Integratie van arbeid en techniek in de ontwerpfase. De vormgever adviseerde ons om de aanvankelijke titel met 'sociaal innovatief' erin te veranderen in 'sociaal inventief'. In 1996 hield prof.dr. Jan Kees Looise zijn oratie aan de Technische
Universiteit van Twente met als titel: 'Sociale innovatie moet, maar hoe?'

Wat is hier de innovatie? Een Centrum voor sociale innovatie hebben we allang gehad met de COP, later COB/SER? En 'sociale innovatie' is oude wijn in nieuwe zakken?

Ja..., nou en...? Deze oude wijn is van goede kwaliteit en moet meer gedronken worden en als nieuwe zakken daarbij helpen, prima.

Sociale innovatie is steeds nodig om de vernieuwde competenties van werknemers te benutten en om organisaties ontvankelijk te maken voor de toepassing van nieuwe kennis en technologie.

Extra aandacht voor sociale innovatie is vooral noodzakelijk als er een sterke vernieuwende impuls moet worden gegeven aan de ontwikkeling van de economie, zoals in de periode vlak na de Tweede Wereldoorlog. In zo'n crisissituatie zijn we nu niet, maar van diverse zijden wordt wel de noodklok geluid. Wij blijven achter in productiviteitsgroei. We halen de ambitie van de Lissabon-agenda niet om de meest concurrerende kenniseconomie te worden. We moeten innoveren en vooral slimmer werken om sneller en goedkoper, nieuwe en betere producten en diensten op nieuwe manieren aan de man te brengen. Het Innovatieplatform is ervoor opgericht.

Het Innovatieplatform onderkent het belang van sociale innovatie, naast technische voor de verbetering van onze nationale concurrentiepositie. Het Innovatieplatform heeft diverse bestaande aanzetten bij elkaar gebracht in een Initiatiefgroep sociale innovatie. In deze initiatiefgroep participeerden: de AWVN, FNV

* De auteur is programmamanager bij TNO Kwaliteit van Leven; zij was namens TNO lid van de initiatiefgroep voor het Centrum voor Sociale Innovatie van het Innovatieplatform en bereidt nu met de partners de echte start voor. 
Bondgenoten en CNV Bedrijvenbond en drie kennisinstellingen: de RMS van de Erasmus Universiteit in Rotterdam, TNO en het AIAS van de Universiteit van Amsterdam. Dit initiatief heeft geresulteerd in de oprichting van het Centrum voor Sociale Innovatie. Het CSI heeft de zegen van het Innovatieplatform, en financiering vanuit het bedrijfsleven en vanuit de ministeries voor EZ, SZW en OC\&W: twee miljoen jaarlijks voor vijf jaren.

Gaan we met dit CSI nu de geschiedenis van het COP en COB/SER herbeleven? In een aantal opzichten mag ik hopen van wel. Het COP was een netwerkorganisatie van en voor het bedrijfsleven waarin veel kennis werd opgenomen, uitgewisseld en ontwikkeld in een open proces. Dat stel ik me ook voor van het CSI. Er waren ook sterke links met het industriebeleid van de overheid. Ik hoop dat we met het programma van het CSI ook goede links zullen hebben met het beleid ter ontwikkeling van kennisregio's en sleutelgebieden voor de ontwikkeling van de economie. Maar dan nu... 'van onderop'!

Want wat we moeten voorkomen, is dat het CSI - zoals het COP en COB in latere jaren vermangeld wordt in de 'Haagse politiek' van regering en sociale partners op centraal niveau. Dat risico lopen we nu echter minder, omdat dit initiatief aansluit bij wat in bedrijven en instellingen al begonnen is en dat wil versterken en verspreiden.

Ik zou voorts wensen dat we in het CSI minstens zoveel interessante projecten uitvoeren en publicaties zullen maken als het COP/ COB heeft gedaan. Maar ik hoop vurig dat deze kennisproductie en -verspreiding meer impact heeft in bedrijven en instellingen dan, naar ik meen, de publicaties van deze SERcommissie hebben gehad. Op veel van deze bedrijfskundige, arbeidskundige en managementkennis is ook de innovatieparadox van toepassing. Interessante modellen, concepten, technieken en best practices zijn ontwikkeld of beschreven, maar slechts hier en daar is die kennis in de praktijk toegepast of overgenomen. Veel bedrijven vinden liever zelf uit hoe ze zich intern moeten organiseren. Voorzover zij hierin innoveren, is dit een vorm van gesloten innovatie. Zij missen daardoor kansen! Het lijkt erop dat de sociale partners in de COB/SER - vooral de laatste jaren - hebben gevochten als twee honden om een been en dat de professionals, wetenschappers en adviseurs, er met dat been vandoor zijn gegaan, in de vorm van subsidie voor onderzoek en projecten. Dat nu, is het afschrikwekkend voorbeeld dat het COB/SER voor het CSI ook kan zijn.

Het CSI moet een open platform zijn voor bedrijven, instellingen, werknemers, vakbonden, kennisinstellingen en adviseurs, dat initiatieven vanuit bedrijven en van werknemers honoreert, stimuleert en op een hoger plan brengt door kennisuitwisseling en -toevoeging en door evaluatief onderzoek.

Het Centrum zal zich bezighouden met sociale innovatie in de betekenis van 'vernieuwingen van arbeidsorganisaties en benutting van competenties met het oog op verbetering van de prestaties van die organisaties en ontplooiing van talent'. De vernieuwingen zullen liggen op de gebieden: dynamisch management, flexibel organiseren en slimmer werken.

Twee voorbeelden tot slot.

Het eerste betreft een Philips-bedrijf. Hier heeft TNO met de medewerkers aan een assemblagelijn een alternatief pauzeroulatieschema ontwikkeld. Na enkele weken experimenteren kwamen ze uit op in totaal langer pauzeren in - qua duur - variabele pauzes gedurende de dag. Er waren twee extra mensen nodig aan de assemblagelijn. De output ging met 16 procent omhoog, de kosten werden er ruimschoots uitgehaald. Er waren minder klachten over vermoeidheid en 90 procent van de medewerkers ervoer het nieuwe schema als prettiger.

Het tweede voorbeeld gaat over ziekenhuizen. De Nederlandse Vereniging van Ziekenhuizen (NVZ) gaat samen met de AWVN en TNO projecten Sociale Innovatie in ziekenhuizen ondersteunen. Het gaat hier om een vorm van innovatie van onderop. Groepjes van een manager met enkele medewerkers /verpleegkundigen of mensen van een ondersteunende of paramedische afdeling) gaan in hun eigen werksituatie systematisch onderzoeken wat slimmer kan. Ze beoordelen de combinatie van: organisatie van het zorgproces, technische ondersteuning (bijvoorbeeld ICT) en inzet van personeel. Zij gaan die slimme oplossingen invoeren en het effect ervan evalueren op basis van zelfgekozen prestatie-indicatoren. 